Article

\title{
Physiochemical Characterization of $\alpha$-Amylase as Crosslinked Enzyme Aggregates
}

\author{
Xiaodong $\mathrm{Li}^{1,2}{ }^{\mathbb{D}}$, Zefen $\mathrm{Yu}^{1}{ }^{1}$, Zhaohui Bian ${ }^{1}$, Jianping $\mathrm{Xu}{ }^{1}$, Li Zhang ${ }^{1}$ and Min Qiao ${ }^{1, *(1)}$ \\ 1 Laboratory for Conservation and Utilization of Bio-Resources and Key Laboratory for Microbial Resources \\ of the Ministry of Education, Yunnan University, Kunming 650091, China; microbelee@126.com (X.L.); \\ zfyuqm@hotmail.com (Z.Y.); bianzhaohui2012@outlook.com (Z.B.); jpxumcmaster@gmail.com (J.X.); \\ zl276165392@hotmail.com (L.Z.) \\ 2 College of Pharmacological Sciences, Zhejiang University, Hangzhou 310058, China \\ * Correspondence: qiaoming@ynu.edu.cn; Tel.: +86-871-6503-2538
}

Received: 15 July 2018; Accepted: 24 July 2018; Published: 26 July 2018

\begin{abstract}
Starch is promising candidate material for enhancing the catalytic activity of $\alpha$-amylase during the crosslinking process. To help meet industrial needs, here we tested the influence of bovine serum albumin (BSA) and starch on the performance of crosslinked $\alpha$-amylase aggregates (CLEA), $\alpha$-amylase-prepared as CLEA with starch (CLEA-S), and BSA (CLEA-BSA). Our results showed that the activities of CLEA, CLEA-S, and CLEA-BSA were 1.1-, 1.0-, and 0.74-fold higher than the free $\alpha$-amylase, respectively. The stability of the immobilized enzyme slightly changed. After immobilization, the enzyme increased its $\mathrm{pH}$ and temperature ranges with the optimal $\mathrm{pH}$ values of 5.5, 7.5, 5.5, respectively for CLEA, CLEA-S, and CLEA-BSA, and an upper temperature limit of $50{ }^{\circ} \mathrm{C}$ for all three immobilized forms. Among the three immobilized forms, the CLEA-S was the most thermostable, losing only $3 \%$ of its initial activity during $390 \mathrm{~min}$ incubation at $50{ }^{\circ} \mathrm{C}$. Our microscopic observations of CLEA-S showed that porous structures were formed and such structures could help substance diffusion. In addition, there was excellent affinity between CLEA-S and the substrate. The results suggest that CLEA-S have great potential for industrial application, including for use in starch-based alcohol fermentation.
\end{abstract}

Keywords: crosslinked aggregates; $\alpha$-amylase; starch; protective agent; substrate

\section{Introduction}

Enzyme immobilization significantly improves the properties of enzymes, such as activity, $\mathrm{pH}$, thermal stability, etc. [1-3]. Among various immobilization methods, enzyme attachment on solid surface by physical adsorption or covalent bonding is one of the most practical techniques $[4,5]$. Stabilization of enzymes has been considered to be improved via immobilization, but enzyme stability may decrease after random immobilization [6]. The multipoint covalence and the porous structure in the carrier can help the enzyme molecule reduce any conformational changes associated with enzyme inactivation (such as heat, organic solvents, and extreme $\mathrm{pH}$ ), ultimately increasing enzyme stability and resistance to inhibitors or chemicals [6].

In recent years, carrier-free immobilization is becoming common. The carrier-free forms include crosslinked enzyme aggregates (CLEA) and combi-CLEA [5]. CLEA refers to an immobilized enzyme preparation that is precipitated by adding either a polymer such as polyethylene glycol, a water-miscible organic solvent, or a salt to the aqueous enzyme solution $[3,7,8]$. Subsequently, the enzyme molecules form a physical aggregate by the action of a bifunctional crosslinker such as glutaraldehyde. The catalytic efficiencies of hydrolases, lyases, and oxidoreductases have all been improved by immobilization $[3,5,9]$. CLEA has advantages over other immobilized enzymes, including 
covalent immobilization and physical adsorption (with or without porous supports), and crosslinked enzyme crystals (CLECS) [10,11]. This approach offers the possibility of using semipurified enzymes and the opportunity to combine the immobilization of different enzymes, resulting in higher enzyme activity and mechanical stability than crosslinking enzymes (CLEs). The excellent activity and operational stability obtained without purification by crystallization means that CLEA would be more effective than CLECs in industrial production involving enzymes [12].

CLEA also has several disadvantages, including low mechanical resistance, diffusion problems, mass transfer limitations, and difficulties in filtration and industrialization [11,13]. To overcome some of these problems, different strategies have focused on: (i) trying to enhance high levels of activity recovery and tolerance $[5,14,15]$, like using various precipitating agents (salts, water-miscible organic solvents, or nonionic polymers) and crosslinking agents (glutaraldehyde or dextran polyaldehyde) to enhance high levels of activity recovery and tolerance $[5,14,15]$; (ii) improving the recovery and stability of the enzyme after immobilization using magnetic particles or polymer materials $[16,17]$; and (iii) increasing rapid-reaction capability of the enzymes by means of combi-CLEAs and cascade processes [11].

During CLEA preparation processes, activity or stabilization of the final CLEA is directly affected by the effect of the precipitating agent, crosslinker type, and protect agent [11,15]. Glutaraldehyde is generally the crosslinking agent of choice as it is cheap and readily available in commercial quantities. The low content of lysine in the target enzyme will lead to the failure of CLEA preparation because it plays an important role in the crosslinking step [18]. The problem can be solved by precipitating proteins with polymers containing primary amino groups, such as polylysine and polyethyleneimine (PEI) [19], and also use of bovine serum albumin (BSA) as a protein feeder that serves as source of protein and amino groups to carry out the crosslinking of the enzyme of interest.

Substrate could efficiently protect the active center of the enzyme, adding the substrate during immobilization and crosslinking may help maintain the enzyme's conformational flexibility [20]. Based on this logic, here we try to find a strategy to enhance the performance of crosslinked $\alpha$-amylase aggregates that is exquisitely simple, amenable to rapid optimization, low cost, and industrially applicable.

Alpha-amylase is an important industrial catalytic agent. To enhance its industrial application, it has been immobilized with many methods, including entrapment, covalent binding, and noncovalent adsorption [14,21-24]. These immobilizations are often achieved by chemical and physical methods, which have resulted in changes in catalytic activity, $\mathrm{pH}$-dependency, thermostability, and storage stability. However, the usage time of most immobilized enzymes in industry is typically short. In this study, CLEA of $\alpha$-amylase were prepared to overcome these defects that existed in traditional methods. We added a protective agent involving either starch, which is a substrate of the enzyme, or BSA as a protein feeder to protect the crosslinking effect of the enzyme during crosslinking with glutaraldehyde as the crosslinking agent. The addition of BSA as a protein feeder [25,26] has shown to be capable of enhancing catalytic efficiency, affinity for substrate, and operational stability of $\alpha$-amylase. However, it has not been reported whether starch can be a protective agent during the preparation of CLEA of $\alpha$-amylase (CLEA-S). We hypothesized that the addition of BSA or starch would keep the conformation of the enzyme during the crosslinking process [27]. To test this hypothesis, we prepared CLEA, CLEA-S, and CLEA-BSA from crude alpha-amylase and characterized their optimum $\mathrm{pH}$, optimum temperature, kinetic parameters, microstructure, recycling, storage, and thermal stabilities and compared them with those of the enzyme in free form. Our results showed greater stability and higher activity of CLEA-S as compared to other forms.

\section{Results}

In this study, BSA and starch were assessed for their potential protective effects for $\alpha$-amylase during immobilization. Figure 1 shows the three steps of CLEA preparation. In the first step, the protein agents were mixed into a free amylase solution to combine with the activity site of enzyme; in the second step, enzyme molecules and protein agent coaggregated in the mixture and precipitate; and in 
the third step, CLEA were formed and covalently bonded to the matrix or crosslinked with each other like a network.

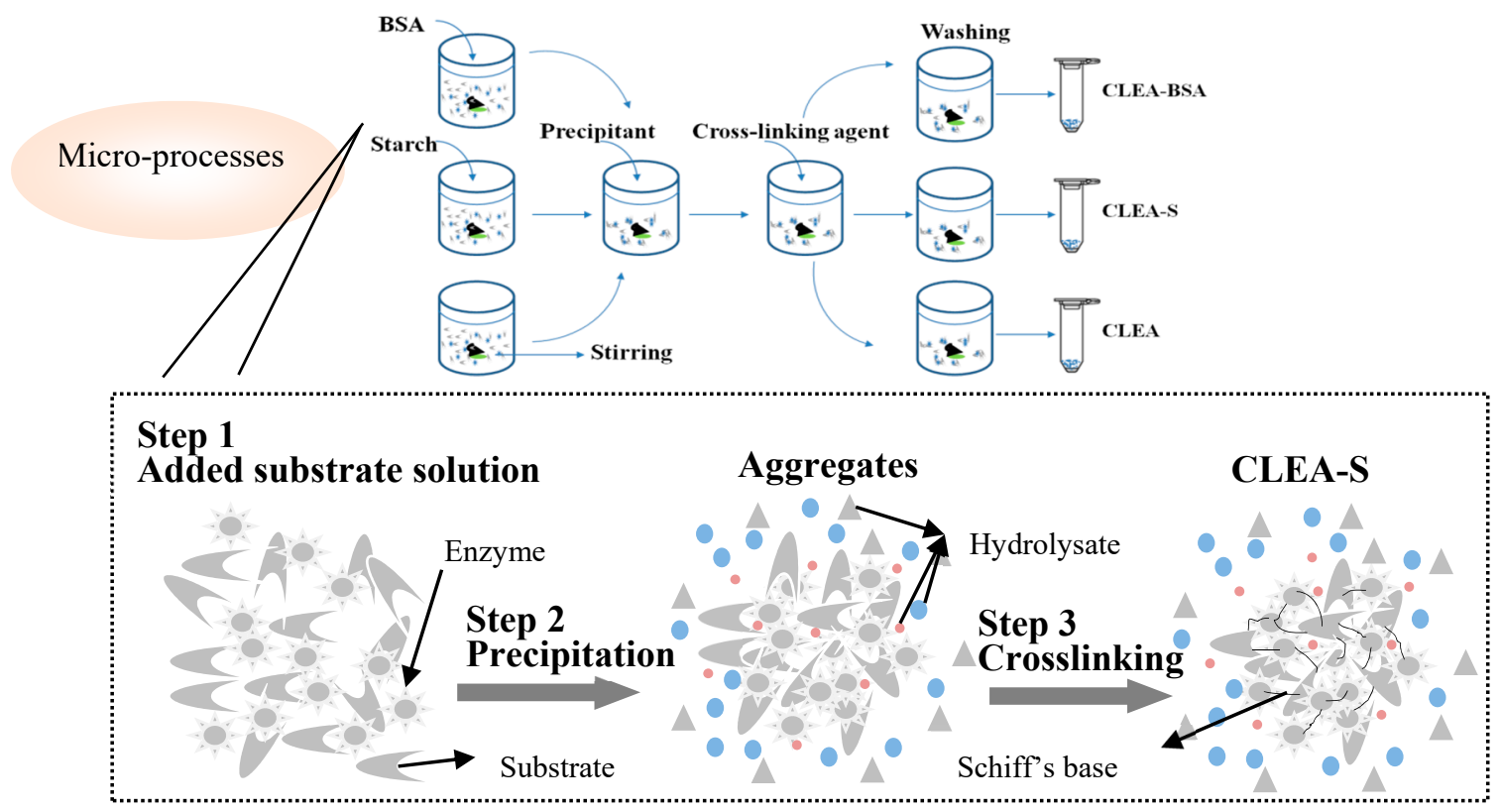

Figure 1. Schematic illustration of the preparation of $\alpha$-amylase-prepared as crosslinked $\alpha$-amylase aggregate with starch (CLEA-S).

\subsection{Effect of Protecting Agents on CLEA Preparation}

\subsubsection{Effect of Starch Concentration as a Substrate Protective Agent}

The preparation of the enzyme solution used in the present work contained $1 \mathrm{mg} / \mathrm{mL} \alpha$-amylase. In the $2 \%(v / v)$ of starch solution, recovery activity of CLEA-S increased by over $10 \%$ of the free enzyme. In the absence of starch during its preparation, enzyme activity was only $78 \%$ of the free enzyme.

Figure $2 \mathrm{~A}$ shows $110 \%$ relative activity recovery when the final concentration of glutaraldehyde was $0.3 \%(v / v)$. When too little crosslinker was used, few CLEA could be obtained.

(A)

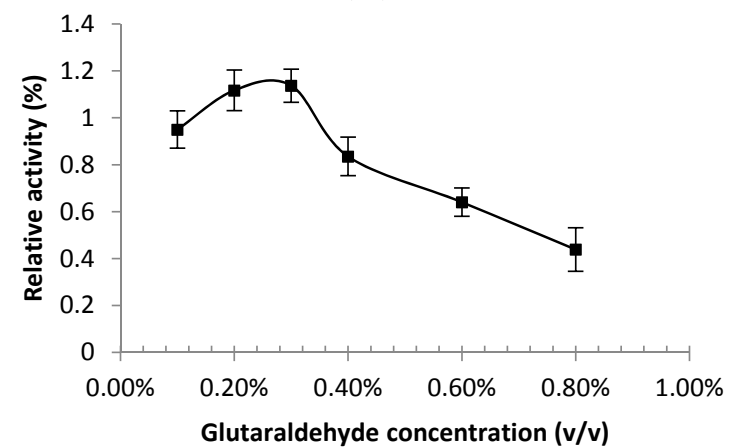

(B)

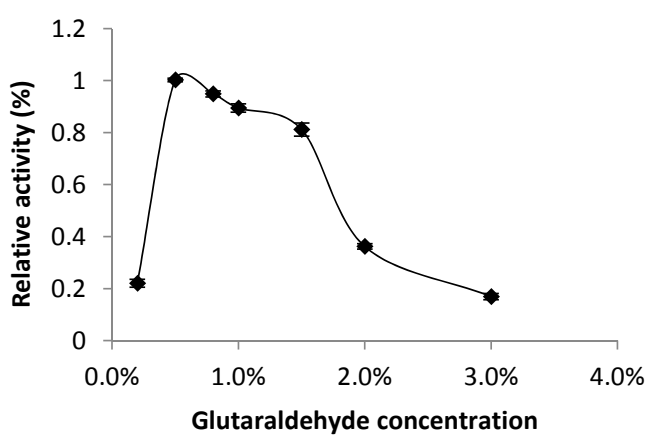

Figure 2. (A) Effect of glutaraldehyde on CLEA activity. Assuming the initial activity of free enzyme was $100 \%$. (B) Effect of glutaraldehyde on CLEA-bovine serum albumin (CLEA-BSA) activity (50 mg of BSA was added in $1 \mathrm{~mL} \alpha$-amylase solution). Assuming the initial activity of free enzyme was $100 \%$. 


\subsubsection{Effect of BSA as a Protein-Protecting Agent during CLEA Preparation}

Results in Figure 2B show a higher activity recovery when both the glutaraldehyde (final concentration was $0.5 \%, v / v$ ) and BSA (final concentration was $50 \mathrm{mg} / \mathrm{mL}$ ) were added during the preparation of CLEA. Protein aggregates and the equivalent of $100 \%$ of the free enzyme activity were obtained when $0.5 \%(v / v)$ of crosslinked agent was added.

\subsection{Effect of $\mathrm{pH}$ on Preparation Enzyme}

The effects of $\mathrm{pH}$ on the activities of immobilized and free enzymes were examined in the range of 3.5-9.0 at $45{ }^{\circ} \mathrm{C}$. These reactions were carried out in a citrate and phosphate buffer solution. As is shown in Figure 3A, the optimal $\mathrm{pH}$ of free $\alpha$-amylase for starch degradation was $\mathrm{pH} 6.5$, and maximum activity of other forms of enzymes in the range of 5-7.0. Furthermore, the $\mathrm{pH}$ profile of the CLEA and CLEA-S was broader than that of the free enzyme, and, after immobilization of the enzyme, the optimal $\mathrm{pH}$ has changed ( $\mathrm{pH}$ 5.5). The optimum range of $\mathrm{pH}$ value for CLEA-BSA was $\mathrm{pH} 4.5-7$ and for CLEA-S was pH 5.5-7.0. Starch and protein combine with enzyme molecules respectively, forming a stable structure of blocking ions from destroying active sites, and finally providing a good reaction environment for enzymes. The activity of the free enzyme decreased rapidly at $\mathrm{pH} 7.0-8.0$, but the activities of CLEA, CLEA-S, and CLEA-BSA were relatively more stable at these $\mathrm{pH}$ values. These results demonstrate that the free enzyme was more sensitive to basic environments than the aggregated forms.

(A)

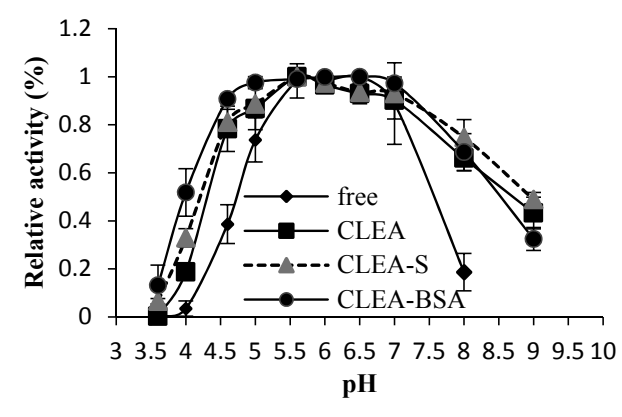

(B)

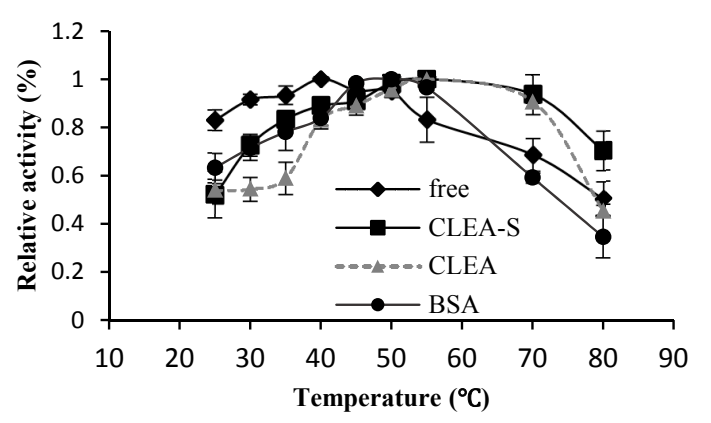

Figure 3. (A) $\mathrm{pH}$ profiles of the free and immobilized $\alpha$-amylase. Rates of hydrolysis are expressed as percentage of the maximal activity. (B) Temperature dependence of native and immobilized $\alpha$-amylase. Rates of hydrolysis are expressed as percentage of the maximal activity.

\subsection{Effect of Temperature on Enzyme Preparations}

Our results showed that the optimal temperatures of free alpha-amylase, CLEA, CLEA-S, and CLEA-BSA were $40{ }^{\circ} \mathrm{C}, 55{ }^{\circ} \mathrm{C}, 55{ }^{\circ} \mathrm{C}$, and $50{ }^{\circ} \mathrm{C}$, respectively (Figure 3B). The immobilized enzymes maintained more than $54.2 \%$ relative activity of the free enzyme in the range of $25-70{ }^{\circ} \mathrm{C}$. Under the action of protecting agent, CLEA and CLEA-S had a broader tolerance range to high temperature, of which CLEA-S remain above $70 \%$ of relative activity at $30-80{ }^{\circ} \mathrm{C}$. In addition, the free enzyme had a higher catalytic activity at lower temperature $\left(<40^{\circ} \mathrm{C}\right)$ than the immobilized forms.

\subsection{Thermal Stability}

The time-activity curve of dynamic thermostability test in both the free and the CLEAs was conducted by incubating the enzyme preparations in the absence of substrate at 50,60 , and $70{ }^{\circ} \mathrm{C}$ with different time intervals (Figure 4). At $70^{\circ} \mathrm{C}$, all four forms showed rapid decline of enzymatic activities, with CLEA-BSA showing the most obvious decline, followed by the free form, CLEA, and CLEA-S. At $60{ }^{\circ} \mathrm{C}$, the decreases were less obvious, with the free form again showing the biggest decline. 
At $50{ }^{\circ} \mathrm{C}$, the largest decline was found in CLEA-BSA, with both CLEA-S and CLEA maintaining over $80 \%$ of initial enzymatic activity even after $390 \mathrm{~min}$.

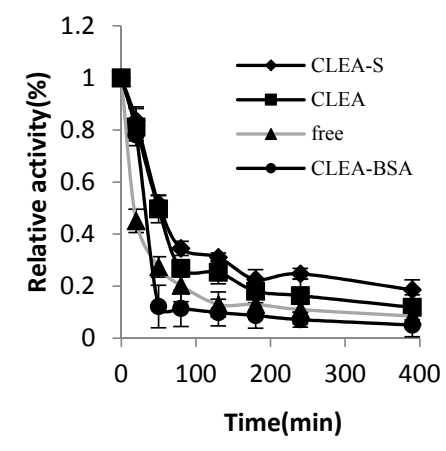

(A) incubated at $70^{\circ} \mathrm{C}$

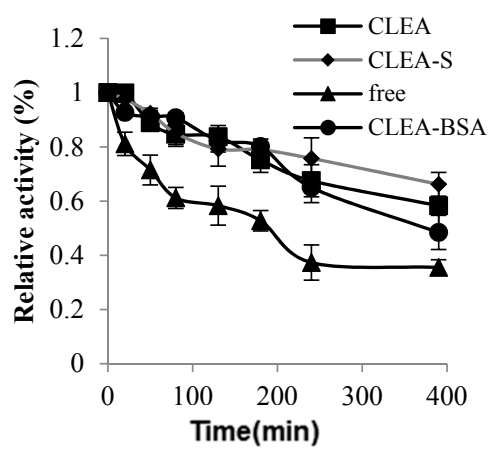

(B) incubated at $60^{\circ} \mathrm{C}$

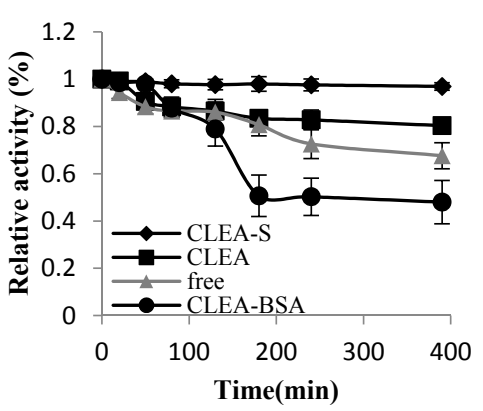

(C) incubated at $50^{\circ} \mathrm{C}$

Figure 4. Comparison of thermal stability of four types of $\alpha$-amylase. Solution starch $2 \%(w / v)$ in $100 \mathrm{mM}$ phosphate buffer ( $\mathrm{pH}$ 7.0) was incubated with enzyme at 50, 60, and $70{ }^{\circ} \mathrm{C}$, respectively. Rates of hydrolysis are expressed as percentage of the maximal activity.

The half-life $\left(t_{1 / 2}\right)$ and the initial first-order thermal inactivation rate constant $\left(k_{\mathrm{i}}\right)$ were calculated from the plot of the residual activity of four forms of $\alpha$-amylases which were incubated at 50, 60, and $70{ }^{\circ} \mathrm{C}$, respectively.

\subsection{Reusability of Immobilized Enzymes}

The reusability of immobilized enzymes was examined by using the same systems repeated 18 times continuously and washed before each use. Figure 5 shows the relative activity of immobilized enzymes after repeated use. Among the three treatments, though all three showed decreased activities over time, CLEA-BSA maintained the highest enzymatic activity throughout the 18 times. The downward trends were quite similar between CLEA-S and CLEA over the 18 times. In all three forms, over $50 \%$ of enzymatic activities were maintained even after 18 washes, with the CLEA-BSA form maintaining nearly $80 \%$ after 18 washes. The activity of CLEA-BSA was 1.34 and 1.46-fold higher than CLEA-S and CLEA at the end of the experiment. CLEA-BSA exhibited good mechanical properties and stable enzyme activity as a protective agent. Starch solution was added in the crosslinking process of $\alpha$-amylase, which increased the stability of the $\alpha$-amylase configuration and made it more robust. There is not a satisfactory explanation so far about this; we surmised that starch as a matrix of CLEA was bulging under normal use so higher catalytic activity obtained was due to the catalyst dispersed in starch solution as fine particles [28].

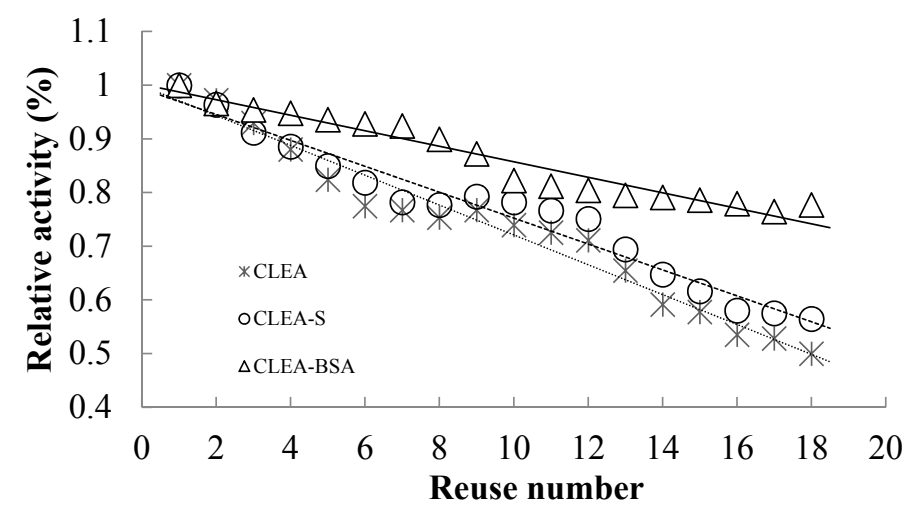

Figure 5. Recovery of immobilized enzymes. Assuming the initial enzyme activity was 100\%. 


\subsection{Scanning Electron Microscope (SEM)}

Figure 6 shows the SEM micrographs of CLEA of $\alpha$-amylase prepared with or without the presence of a protective agent at a magnification of $20 \mathrm{k} \times, 7 \mathrm{k} \times$, and $12 \mathrm{k} \times$. Figure $6 \mathrm{~A}$ shows that the pores and channels of CLEA were larger than starch molecule to pass through without much diffusion limitation. The absence of a protective agent CLEA looks like a normal chemically crosslinked enzyme, which could create an environment to resist external perturbation. The micrograph of Figure 6B shows stratiform and porous morphology, and the enzyme microaggregates have a smaller diameter than that without the protecting agent, generating a higher surface area and more catalytic activity. CLEA bonded on starch molecule and the solid organic structure provided the frame for the enzyme to be accommodated [29]. The surface of CLEA-BSA was rough (Figure 6C) and can increase the exchange rate of the substrate. CLEA-BSA showed a strong robustness to external perturbation likely due to the protection from more protein molecules bonded or adsorbed together with $\alpha$-amylase molecules.

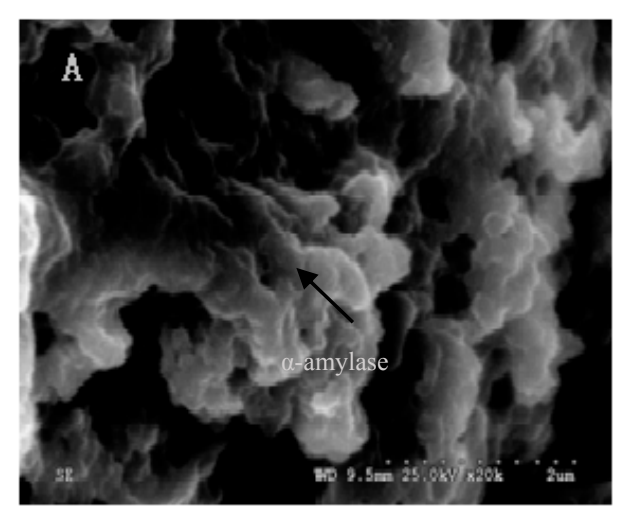

$\operatorname{CLEA}(0.2 \%, v / v)$

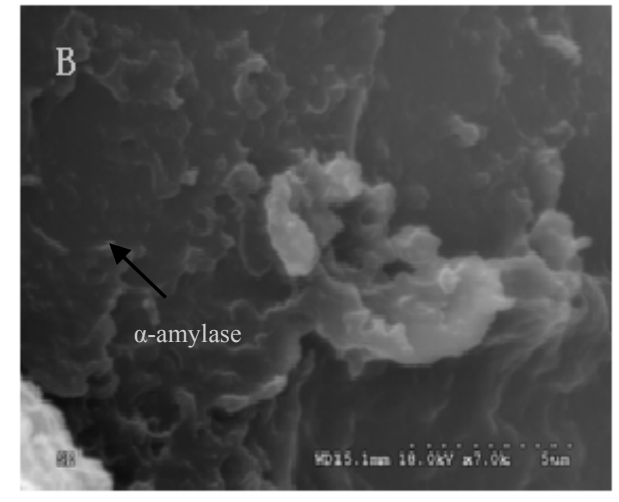

CLEA-S $(0.2 \%, v / v)$

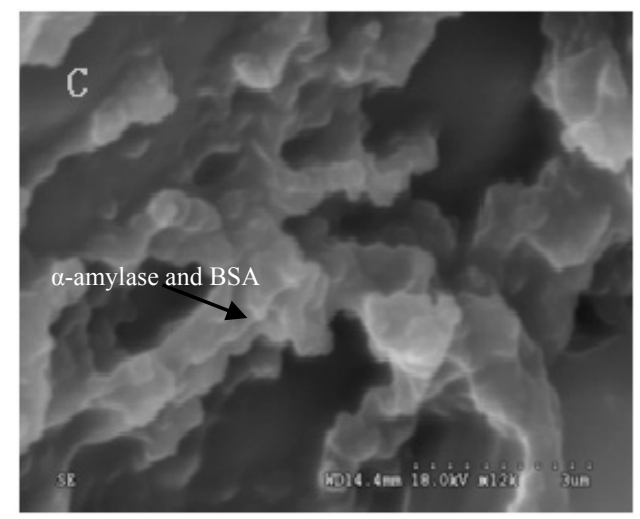

CLEA-BSA $(50 \mathrm{mg} / \mathrm{mL}, 0.5 \%, v / v)$

Figure 6. Scanning electron micrographs of (A) $\alpha$-amylase CLEA absence of starch with $0.2 \%(v / v)$ glutaraldehyde concentration and magnified 20,000 $\times$; (B) CLEA with $2 \%$ starch solution and $0.2 \%$ $(v / v)$ glutaraldehyde concentration, magnified $7000 \times$; (C) CLEA with $50 \mathrm{mg} / \mathrm{mL}$ BSA, and $0.5 \%(v / v)$ glutaraldehyde, magnified $12,000 \times$.

\subsection{Kinetic Studies}

Kinetic parameters of native and immobilized $\alpha$-amylase (apparent values) were examined by measuring the initial reaction rates at a substrate concentration range from 0.5 to $3 \%$. The Michaelis-Menten constant $\left(K_{\mathrm{m}}\right)$ and velocity maximum $\left(V_{\max }\right)$ were observed for the free and immobilized enzymes from Lineweaver-Burk plot. From the way of Table 1, the soluble chemical modification of the enzyme resulted in an increase of the $K_{\mathrm{m}}$ values. The $K_{\mathrm{m}}$ for CLEA, CLEA-S, 
and CLEA-BSA were approximately 6.12-, 3.58-, and 3.09-fold higher than that of the free enzyme, respectively. The $V_{\max }$ of CLEA-S is the lowest value in the data of Table 1 , just over a quarter of the native free enzyme or CLEA-BSA.

Table 1. Kinetic parameters of native and immobilized enzyme at $45^{\circ} \mathrm{C}$.

\begin{tabular}{|c|c|c|}
\hline Types & $K_{\mathrm{m}}\left(\mathrm{mg} \cdot \mathrm{mL}^{-1}\right)$ & $V_{\max }\left(\mathrm{mg} \cdot \mathrm{mL}^{-1} \cdot \min ^{-1}\right)$ \\
\hline Native free enzyme & $1.46 \pm 0.35$ & $81.3 \pm 0.71$ \\
\hline CLEA & $8.94 \pm 0.68$ & $37.7 \pm 0.22$ \\
\hline CLEA-S & $5.24 \pm 0.29$ & $23.5 \pm 0.12$ \\
\hline CLEA-BSA & $4.52 \pm 0.45$ & $82.6 \pm 0.63$ \\
\hline
\end{tabular}

\subsection{Storage Stability}

The reusability and robustness of CLEA were examined by multiple usages. CLEA-S displayed reusability after 25 times of discontinuous reuses and it retained more than $65 \%$ of initial activity. In the experiment, the reduction rate of enzyme activity was $35 \%$ after 12 times of repeated use of CLEA-BSA compared with the initial one. Both the free and immobilization $\alpha$-amylase retained more than $75 \%$ relative activity after storing for two months at room temperature. In another month's time, however, the residual activity of CLEA-BSA and CLEA-S still maintained $65 \%$ and $70 \%$ activities, respectively. By contrast, the free enzyme only had $40 \%$ activity left. The results showed that the enzyme activity of CLEA-S and CLEA-BSA were less affected by storage. Therefore, substrate as a protective agent could enhance the storage stability of immobilized enzyme.

\section{Discussion}

Glutaraldehyde, a small reactive molecule, is a common crosslinking agent of choice. The reagent can penetrate the internal structure of enzymes and react with amino acid residues. Some of these amino acid residues are often important sites for the catalytic activity of the enzyme [11,30,31]. Figure 2A,B showed that the amounts of CLEA were increased with the increasing crosslinker concentration. However, when the crosslinker concentration reached a high concentration, the enzyme activity started to decrease [32]. A large number of enzyme molecules can be lost during washing. As a result, if the concentration of the crosslinking agent is too low, it can lead to low crosslinking. As an extra source of protein feeder, BSA increases the free lysine residue that can prevent the inactivation of $\alpha$-amylase [33]. For CLEA-S, the conformational flexibility of CLEA-S is also affected by immobilization, although the addition of starch during immobilization increases the rigidity and stability of the enzyme at high temperature [32]. As reported previously [20], substrate could efficiently protect the active site of the enzyme during crosslinking. However, a high substrate concentration can limit the interchange between substrates and products.

The activity of CLEA changed with the addition of the substrate during its coimmobilization. As shown in Figure 1, the protective effect of CLEA-S could be due to either the substrate or the degradation products. The presence of starch makes the immobilized enzyme form a stable and effective CLEA, which improves the spatial structure of CLEA and the orientation of the immobilized enzyme. The starch also decreases the enzyme loading and diffusion problems. The complex organic system of coaggregation form stable activity was similar to being "locked", which is constructed following Schiff's base by chemical groups of substrate, degradation products, and enzyme molecules in crosslinking and catalytic process [27]. In addition, the $\alpha$-amylase active site was protected by "setup protection", which means these reactions combine active sites with optimal concentration of substrate to avoid excessive crosslinking of the amino acid residues at the $\alpha$-amylase catalytic sites. Furthermore, affinity of $\alpha$-amylase with substrates decreased under crosslinked immobilization, but the $K_{\mathrm{m}}$ values did not differ much between CLEA-S and CLEA-BSA. These results suggest that starch is a potentially better protective agent than CLEA-BSA. 
For all three types of immobilized forms examined here, both their thermal and storage stabilities were enhanced when compared to the free form. Their optimal $\mathrm{pH}$ and temperature profiles were broader than those of the free enzyme. More significantly, CLEA-S showed a higher thermostability than the other two types of immobilized forms and the free form at $50{ }^{\circ} \mathrm{C}$ and $60{ }^{\circ} \mathrm{C}$, which means the substrate as a protecting agent during crosslinking was effective in protecting the catalytic site of this enzyme. The immobilized enzymes showed excellent catalytic performance by continuous reuse, especially CLEA-BSA, which maintained 80\% initial activity even after 18 runs. Similarly, both CLEA and CLEA-S showed a high capability and a long service life.

\section{Methods}

\subsection{Materials}

Alpha-amylase from Bacillus subtilis was donated as a crude enzyme powder by Luliang Co., Ltd. (Luliang, China). BSA was purchased from Sigma Chemical Co. (St. Louis, MO, USA). Substrates for enzymatic activity assays were of analytical pure grade and obtained from Sinopharm Chemical Reagent Co., Ltd. (Shanghai, China). Glutaraldehyde solution (50\% v/v in water) was obtained from the Standard Sci and Tech Co., Ltd. (Tianjin, China). Sodium borohydride (>96\% $w / w)$ and 3.5-Dinitrosalicylic acid $(>98 \% w / w)$ were supplied by Sinopharm Chemical Reagent Co., Ltd. (Shanghai, China). All other reagents used were of analytical pure grade. All the solutions were prepared with deionized water.

\subsection{Preparation of $\alpha$-Amylase Solution}

Alpha-amylase ( $2 \mathrm{~g}$ crude enzyme powder) was added to $80 \mathrm{~mL}$ sodium phosphate buffer $(100 \mathrm{mM}, \mathrm{pH} 7)$ in a $200 \mathrm{~mL}$ beaker and was gently mixed with a magnetic stirrer for $15 \mathrm{~min}$ at room temperature. After centrifugation, the supernatant containing the enzyme solution was transferred to a new tube and the enzyme was precipitated by adding solid ammonium sulfate, and stirred for $20 \mathrm{~min}$. The precipitate was collected by centrifugation with $2240 \mathrm{RCF}$ at $10^{\circ} \mathrm{C}$ for $15 \mathrm{~min}$; after that, $60 \mathrm{~mL}$ sodium phosphate buffer $(100 \mathrm{mM}, \mathrm{pH} 7)$ was added and agitated for $15 \mathrm{~min}$ at room temperature. The enzyme solution was dialyzed in a dialysis bag $(8000 \mathrm{Da})$ for $24 \mathrm{~h}$. The collected enzymatic solution was diluted with the PBS (pH 7.0, Sigma-Aldrich Co. Ltd., MO, USA) buffer to $80 \mathrm{~mL}$. In subsequent experiments, the enzyme solution was not further purified.

\subsection{Alpha-Amylase Assay}

Alpha-amylase activity was assayed with the method described by Miller [34-36]. Briefly, $\alpha$-amylase activity was determined at $45^{\circ} \mathrm{C}$, using $1 \%$ soluble starch as substrate at $\mathrm{pH} 7 \mathrm{in}$ phosphate buffer $(100 \mathrm{mM})$. The reaction was terminated with a dinitrosalicylic acid solution (DNS). One unit of $\alpha$-amylase activity was defined as the amount of enzyme that releases $1 \mathrm{mg} / \mathrm{mL}$ of reducing sugars (maltose equivalents) under the assay conditions.

The quantitatively-weighed CLEA particles were added to $400 \mu \mathrm{L}$ of phosphate buffer $(100 \mathrm{mM}$, $\mathrm{pH} 7$ ) and placed in a $50^{\circ} \mathrm{C}$ water bath for $5 \mathrm{~min}$. At the same time, a $1 \%$ starch solution was preheated in a $45^{\circ} \mathrm{C}$ water bath for $10 \mathrm{~min}$ and then added to the reaction solution and mixed well. The mixed reaction solution was quickly placed in a $45^{\circ} \mathrm{C}$ water bath for another $15 \mathrm{~min}$. The reaction mixture was added $2 \mathrm{~mL}$ of DNS reagent, placed in a boiling water bath for $5 \mathrm{~min}$, cooled rapidly, and adjusted to $20 \mathrm{~mL}$ with double-distilled water. The same operation was carried out with distilled water as the control instead of starch. The absorbance (OD value) of the reaction liquid was determined at $520 \mathrm{~nm}$ with a 722 type spectrophotometer. The enzyme activity of CLEA is calculated as follows:

$$
\text { Relative activity }(\%)=\frac{\mathrm{A}_{2}}{\mathrm{~A}_{1}} \times 100 \%
$$

$\mathrm{A}_{1}$ : sample initial activity; $\mathrm{A}_{2}$ : sample postpreparative activity. 


\subsection{Bacillus Subtilis $\alpha$-Amylase CLEA}

CLEA of $\alpha$-amylase was prepared using a modified procedure originally described by Schoevaart [37]. The enzyme solution $(1.6 \mathrm{~mL})$ was dissolved in a $2 \mathrm{~mL}$ sodium phosphate buffer $(100 \mathrm{mM}, \mathrm{pH}$ 7) in a $25 \mathrm{~mL}$ conical flask and stirred gently at room temperature for $10 \mathrm{~min}$. Then, the powdered precipitant $\left(\mathrm{NH}_{4}\right)_{2} \mathrm{SO}_{4}(2.52 \mathrm{~g})$ was slowly added for protein aggregation with a constant mixing by a magnetic stirrer. After $30 \mathrm{~min}$, glutaraldehyde $(50 \% v / v$ in water) was added to the solution so that the final concentration of glutaraldehyde was $0.2 \%(v / v)$, and the mixture stirred at room temperature at $14 \mathrm{RCF}$ for $2 \mathrm{~h}$. Then, $150 \mu \mathrm{L}$ of a sodium borohydride solution $(100 \mathrm{mM})$ was added to stop the crosslinking of crosslinker and enzyme. Following a 15 min reaction period, the mixture was stored at $4{ }^{\circ} \mathrm{C}$ without stirring for $12 \mathrm{~h}$ to precipitate the CLEA, which was then centrifuged at $8960 \mathrm{RCF}$ at $10{ }^{\circ} \mathrm{C}$ for $10 \mathrm{~min}$. Afterwards, the supernatant was discarded and the aggregates decanted and washed three times with sodium phosphate buffer (100 mM, pH 7). The final aggregation was collected in the buffer at $4{ }^{\circ} \mathrm{C}$. CLEA suspension was centrifuged before the experiment started.

\subsection{Preparation of CLEA-S and CLEA-BSA}

The enzyme solution (1.6 mL) and $2 \mathrm{~mL}$ sodium phosphate buffer (100 mM, pH 7) were slowly added into the $25 \mathrm{~mL}$ conical flask, respectively, and then added equal volume of either a starch solution (in the case of CLEA-S) or a bovine serum albumin solution (in the case of CLEA-BSA). Afterwards, a powdered precipitant $\left(\mathrm{NH}_{4}\right)_{2} \mathrm{SO}_{4}(5.04 \mathrm{~g})$ was slowly added for protein aggregation. After $30 \mathrm{~min}$, glutaraldehyde $(50 \% v / v$ in water) was added so that the final concentration of glutaraldehyde in the crosslinker solution was $0.2 \%(v / v)$, and the mixture was agitated at room temperature for $2 \mathrm{~h}$ at $14 \mathrm{RCF}$. The mixture was then centrifuged at $10{ }^{\circ} \mathrm{C}$ for $10 \mathrm{~min}$ with $8960 \mathrm{RCF}$. Afterwards, the supernatant was discarded, the aggregates decanted and washed three times with sodium phosphate buffer (100 mM, pH 7). The final aggregation was collected in the buffer at $4{ }^{\circ} \mathrm{C}$. The CLEA-S and CLEA-BSA suspensions were centrifuged before the enzymatic activity assays started.

A diagram showing CLEA-S preparation is presented in Figure 1.

\subsection{Protein Assay}

Protein concentration was determined according to the procedure described by Bradford [38], using BSA as the standard substance.

To establish a standard curve, the following solution is added in seven colorimetric tubes respectively in turn: Standard protein $(1.00 \mathrm{mg} / \mathrm{mL}) 0 \mathrm{~mL}, 0.01 \mathrm{~mL}, 0.02 \mathrm{~mL}, 0.04 \mathrm{~mL}, 0.06 \mathrm{~mL}$, $0.08 \mathrm{~mL}, 0.1 \mathrm{~mL}$; double-distilled water $0.1 \mathrm{~mL}, 0.09 \mathrm{~mL}, 0.08 \mathrm{~mL}, 0.06 \mathrm{~mL}, 0.04 \mathrm{~mL}, 0.02 \mathrm{~mL}, 0 \mathrm{~mL}$; G-250 reagent of Kaumas blue (Sigma-Aldrich Co. Ltd.) $3.0 \mathrm{~mL}$ per tube; mixed thoroughly and reacted for $20 \mathrm{~min}$. Then the absorbance was measured at $595 \mathrm{~nm}$ with a 722 type spectrophotometer. The standard protein concentrations $(\mathrm{mg} / \mathrm{mL})$ were used as the $\mathrm{X}$-axis and the OD values as the $\mathrm{Y}$-axis to generate a standard curve.

The OD value of the unknown sample was measured by the operation of the repeated standard curve, and the protein content of the unknown sample was obtained by the following formula:

$$
\mathrm{W}_{1}=\frac{\mathrm{W}_{2} \times \mathrm{V}_{1}}{\mathrm{~W}_{3} \times \mathrm{V}_{2}}
$$

$\mathrm{W}_{1}$ : sample protein content $(\mathrm{mg} / \mathrm{g}) ; \mathrm{W}_{2}$ : the calculated protein content $(\mathrm{mg} / \mathrm{g}) ; \mathrm{V}_{1}$ : the total volume of the extract $(\mathrm{mL}) ; \mathrm{W}_{3}$ : sample weight $(\mathrm{g}) ; \mathrm{V}_{2}$ : the volume of the extraction liquid at the time of determination $(\mathrm{mL})$. 


\subsection{The Optimum Condition of $\alpha$-Amylase Activity}

The effect of temperature and $\mathrm{pH}$ on the activity of the free and immobilized $\alpha$-amylase was determined, in the range of $30-55^{\circ} \mathrm{C}$ and $\mathrm{pH} 3.5-9$, respectively. The results for the most suitable reaction temperature and $\mathrm{pH}$ were given in relative form with the maximum value being $100 \%$ activity.

\subsection{Stability of Prepared Enzyme}

The thermostability of the enzyme in both the free and the CLEAs forms was assessed by incubating the enzyme solutions with $100 \mathrm{mM}$ PBS buffer solution (Sigma-Aldrich Co. Ltd., pH 7.0) at $50{ }^{\circ} \mathrm{C}, 60{ }^{\circ} \mathrm{C}$, and $70{ }^{\circ} \mathrm{C}$ for $30 \mathrm{~min}$, respectively. Result of thermostability was given as residual activities, calculated by taking the initial activity of enzyme solution as $100 \%$. The experiments were carried out in triplicates and error was always below $5 \%$.

\subsection{Kinetic Parameters Analysis}

Kinetic parameters, both of the free $\alpha$-amylase and the immobilized, CLEA, CLEA-S, and CLEA-BSA, were determined in $100 \mathrm{mM}$ sodium phosphate buffer solution ( $\mathrm{pH}$ 7.0) at $45{ }^{\circ} \mathrm{C}$. Kinetic constants of free and immobilized enzymes were calculated based on the classic Michaelis-Menton equation. The initial reaction rate results were determined at various concentrations of starch, and a Lineweaver-Burk plot of $1 /(v)$ versus $1 /(s)$ was employed for $V_{\max }$ and $K_{\mathrm{m}}$ calculations.

\subsection{SEM Analysis}

SEM images were recorded with S3000N (Hitachi, Tokyo, Japan). The shape and surface morphology of free and immobilized enzymes were examined using an SEM. Samples were mounted on metal stubs using double-sided adhesive and sputtered with gold.

\section{Conclusions}

Adding substance during the preparation of immobilized $\alpha$-amylase is a potential strategy to enhance the performance of CLEA. It is possible to achieve this goal through a diversity of mechanisms, including changing the affinity conformation and reducing steric hindrance, which can help immobilize enzymes for industrialized application.

The storage stability of an enzyme is also an important indicator contributing to reducing capital and operational costs in commercial productions. Industrial enzymes account for more than half of the overall costs in many commercial productions. CLEA-S should have a broad applicability for CLEA-S's long storage stability, high tolerance to external extreme environment conditions, and low costs to manufacture. For these reasons, the strategy of starch-based CLEA could be used in a continuous system for the fermentation of ethanol using starch.

Author Contributions: Conceptualization, M.Q.; Methodology, X.L.; Software, Z.Y.; Validation, M.Q.; Formal Analysis, Z.Y.; Investigation, X.L., Z.B. and L.Z.; Resources, M.Q.; Data Curation, Z.Y.; Writing-Original Draft Preparation, X.L.; Writing-Review \& Editing, J.X. and M.Q.; Supervision, M.Q.; Project Administration, M.Q.

Funding: This research was funded by the National Nature Science Foundation of China grant number 31760012 and 31360130 .

Acknowledgments: We are very grateful for generous financial support from the National Nature Science Foundation of China

Conflicts of Interest: The authors declare no conflict of interest. This article does not contain any studies with human participants or animals performed by any of the authors.

\section{References}

1. Sheldon, R.A.; van Pelt, S. Enzyme immobilisation in biocatalysis: Why, what and how. Chem. Soc. Rev. 2013, 42, 6223-6235. [CrossRef] [PubMed] 
2. Bilal, M.; Asgher, M.; Iqbal, H.M.; Hu, H.; Zhang, X. Bio-based degradation of emerging endocrine-disrupting and dye-based pollutants using cross-linked enzyme aggregates. Environ. Sci. Pollut. Res. 2017, 24, 7035-7041. [CrossRef] [PubMed]

3. Bilal, M.; Iqbal, H.M.N.; Hu, H.; Wang, W.; Zhang, X. Development of horseradish peroxidase-based cross-linked enzyme aggregates and their environmental exploitation for bioremediation purposes. J. Environ. Manag. 2017, 188, 137-143. [CrossRef] [PubMed]

4. Datta, S.; Christena, L.R.; Rajaram, Y.R.S. Enzyme immobilization: An overview on techniques and support materials. 3 Biotech 2013, 3, 1-9. [CrossRef] [PubMed]

5. Bilal, M.; Iqbal, H.M.N.; Guo, S.; Hu, H.; Wang, W.; Zhang, X. State-of-the-art protein engineering approaches using biological macromolecules: A review from immobilization to implementation view point. Int. J. Biol. Macromol. 2018, 108, 893-901. [CrossRef] [PubMed]

6. Mateo, C.; Palomo, J.M.; Fernandez-Lorente, G.; Guisan, J.M.; Fernandez-Lafuente, R. Improvement of enzyme activity, stability and selectivity via immobilization techniques. Enzyme Microb. Technol. 2007, 40, 1451-1463. [CrossRef]

7. Cao, L.; van Rantwijk, F.; Sheldon, R.A. Cross-linked enzyme aggregates: A simple and effective method for the immobilization of penicillin acylase. Org. Lett. 2000, 2, 1361-1364. [CrossRef] [PubMed]

8. Cao, L.; Van Langen, L.M.; Van Rantwijk, F.; Sheldon, R.A. Cross-linked aggregates of penicillin acylase: Robust catalysts for the synthesis of $\beta$-lactam antibiotics. J. Mol. Catal. B 2001, 11, 665-670. [CrossRef]

9. Sheldon, R.A. Cross-linked enzyme aggregates (CLEAs): Stable and recyclable biocatalysts. Biochem. Soc. Trans. 2007, 35, 1583-1587. [CrossRef] [PubMed]

10. Rehman, S.; Bhatti, H.N.; Bilal, M.; Asgher, M. Cross-linked enzyme aggregates (CLEAs) of Pencilluim notatum lipase enzyme with improved activity, stability and reusability characteristics. Int. J. Biol. Macromol. 2016, 91, 1161-1169. [CrossRef] [PubMed]

11. Velasco-Lozano, S.; López-Gallego, F.; Mateos-Díaz, J.C.; Favela-Torres, E. Cross-linked enzyme aggregates (CLEA) in enzyme improvement-A review. Biocatalysis 2015, 1, 166-177. [CrossRef]

12. Roessl, U.; Nahálka, J.; Nidetzky, B. Carrier-free immobilized enzymes for biocatalysis. Biotechnol. Lett. 2010, 32, 341-350. [CrossRef] [PubMed]

13. Garcia-Galan, C.; Berenguer-Murcia, A.; Fernandez-Lafuente, R.; Rodrigues, R.C. Potential of Different Enzyme Immobilization Strategies to Improve Enzyme Performance. Adv. Synth. Catal. 2011, 353, 2885-2904. [CrossRef]

14. Nadar, S.S.; Muley, A.B.; Ladole, M.R.; Joshi, P.U. Macromolecular cross-linked enzyme aggregates (M-CLEAs) of $\alpha$-amylase. Int. J. Biol. Macromol. 2016, 84, 69-78. [CrossRef] [PubMed]

15. Sheldon, R.A. Characteristic features and biotechnological applications of cross-linked enzyme aggregates (CLEAs). Appl. Microbiol. Biot. 2011, 92, 467-477. [CrossRef] [PubMed]

16. Talekar, S.; Ghodake, V.; Ghotage, T.; Rathod, P.; Deshmukh, P.; Nadar, S.; Mulla, M.; Ladole, M. Novel magnetic cross-linked enzyme aggregates (magnetic CLEAs) of alpha amylase. Bioresour. Technol. 2012, 123, 542-547. [CrossRef] [PubMed]

17. Cui, J.D.; Cui, L.L.; Zhang, S.P.; Zhang, Y.F.; Su, Z.S.; Ma, G.H. Hybrid magnetic cross-linked enzyme aggregates of phenylalanine ammonia lyase from Rhodotorula glutinis. PLoS ONE 2014, 9, e97221. [CrossRef] [PubMed]

18. Yamaguchi, H.; Miyazaki, M.; Asanomi, Y.; Maeda, H. Poly-lysine supported cross-linked enzyme aggregates with efficient enzymatic activity and high operational stability. Catal. Sci. Technol. 2011, 1, 1256-1261. [CrossRef]

19. López-Gallego, F.; Betancor, L.; Hidalgo, A.; Alonso, N.; Fernández-Lafuente, R.; Guisán, J.M. Co-aggregation of enzymes and polyethyleneimine: A simple method to prepare stable and immobilized derivatives of glutaryl acylase. Biomacromolecules 2005, 6, 1839-1842. [CrossRef] [PubMed]

20. Rosenblum, J.L.; Irwin, C.L.; Alpers, D.H. Starch and glucose oligosaccharides protect salivary-type amylase activity at acid pH. Am. Physiol. Soc. 1988, 2549, 775-780. [CrossRef] [PubMed]

21. Klapiszewski, Ł.; Zdarta, J.; Jesionowski, T. Titania/lignin hybrid materials as a novel support for $\alpha$-amylase immobilization: A comprehensive study. Colloids Surf. B Biointerfaces 2018, 162, 90-97. [CrossRef] [PubMed]

22. Ahmed, S.A.; Mostafa, F.A.; Ouis, M.A. Enhancement stability and catalytic activity of immobilized $\alpha$-amylase using bioactive phospho-silicate glass as a novel inorganic support. Int. J. Biol. Macromol. 2018, 112, 371-382. [CrossRef] [PubMed] 
23. Talekar, S.; Joshi, A.; Joshi, G.; Kamat, P.; Haripurkar, R.; Kambale, S. Parameters in preparation and characterization of cross linked enzyme aggregates (CLEAs). RSC Adv. 2013, 3, 12485-12511. [CrossRef]

24. Talekar, S.; Pandharbale, A.; Ladole, M.; Nadar, S.; Mulla, M.; Japhalekar, K.; Pattankude, K.; Arage, D. Carrier free co-immobilization of alpha amylase, glucoamylase and pullulanase as combined cross-linked enzyme aggregates (combi-CLEAs): A tri-enzyme biocatalyst with one pot starch hydrolytic activity. Bioresour. Technol. 2013, 147, 269-275. [CrossRef] [PubMed]

25. Shah, S.; Sharma, A.; Gupta, M.N. Preparation of cross-linked enzyme aggregates by using bovine serum albumin as a proteic feeder. Anal. Biochem. 2006, 351, 207-213. [CrossRef] [PubMed]

26. Wang, K.; Gao, Y.; Wang, Z.; Meng, G. Cross-linked enzyme aggregates of $\beta$-galactosidase from different source by dialdehyde Starch as Cross-Linker. In Proceedings of the 2012 International Conference on Applied Biotechnology (ICAB 2012); Lecture Notes in Electrical Engineering; Springer: Berlin/Heidelberg, Germany, 2014; Volume 251, pp. 1733-1739.

27. Li, X.D.; Wu, J.; Jia, D.C.; Wan, Y.H.; Yang, N.; Qiao, M. Preparation of cross-linked glucoamylase aggregates immobilization by using dextrin and xanthan gum as protecting agents. Catalysts 2016, 6, 77. [CrossRef]

28. Chang, M.Y.; Juang, R.S. Use of chitosan-clay composite as immobilization support for improved activity and stability of $\beta$-glucosidase. Biochem. Eng. J. 2007, 35, 93-98. [CrossRef]

29. Wang, M.; Qi, W.; Yu, Q.; Su, R.; He, Z. Cross-linking enzyme aggregates in the macropores of silica gel: A practical and efficient method for enzyme stabilization. Biochem. Eng. J. 2010, 52, 168-174. [CrossRef]

30. Barbosa, O.; Ortiz, C.; Ángel, B.M.; Torres, R.; Rodrigues, R.C.; Roberto, F.L. Glutaraldehyde in bio-catalysts design: A useful crosslinker and a versatile tool in enzyme immobilization. RSC Adv. 2014, 4, 1583-1600. [CrossRef]

31. Sheldon, R.A.; Sorgedrager, M.; Janssen, M.H. Use of cross-linked enzyme aggregates (CLEAs) for performing biotransformations. Chim. Oggi 2007, 25, 62-67.

32. Matijošytė, I.; Arends, I.W.; de Vries, S.; Sheldon, R.A. Preparation and use of cross-linked enzyme aggregates (CLEAs) of laccases. J. Mol. Catal. B 2010, 62, 142-148. [CrossRef]

33. Khajeh, K.; Naderi-Manesh, H.; Ranjbar, B.; Moosavi-Movahedi, A.; Nemat-Gorgani, M. Chemical modification of lysine residues in Bacillus $\alpha$-amylases: Effect on activity and stability. Enzyme Microb. Technol. 2001, 28, 543-549. [CrossRef]

34. Miller, G.L. Use of dinitrosalicylic acid reagent for determination of reducing sugar. Anal. Chem. 1959, 31, 426-428. [CrossRef]

35. Bernfeld, P. Amylases, $\alpha$ and $\beta$. Method Enzymol. 1955, 1, 149-158.

36. Sindhu, R.; Binod, P.; Pandey, A. $\alpha$-Amylases. In Current Developments in Biotechnology and Bioengineering; Elsevier: Amsterdam, The Netherlands, 2017; pp. 3-24.

37. Schoevaart, R.; Wolbers, M.W.; Golubovic, M.; Ottens, M.; Kieboom, A.P.G.; van Rantwijk, F.; van der Wielen, L.A.M.; Sheldon, R.A. Preparation, optimization, and structures of cross-linked enzyme aggregates (CLEAs). Biotechnol. Bioeng. 2004, 87, 754-762. [CrossRef] [PubMed]

38. Bradford, M.M. A rapid and sensitive method for the quantitation of microgram quantities of protein utilizing the principle of protein-dye binding. Anal. Biochem. 1976, 72, 248-254. [CrossRef]

(C) 2018 by the authors. Licensee MDPI, Basel, Switzerland. This article is an open access article distributed under the terms and conditions of the Creative Commons Attribution (CC BY) license (http:// creativecommons.org/licenses/by/4.0/). 